\title{
Outrunning COVID-19 II: My Trip to Aeæa
}

\author{
Thomas Steinbuch ${ }^{1}$
}

I live close to my university and I have been taking my meals at the school canteen but it has been shuttered because of COVID-19. Tonight I will make pasta in a double boiler: pasta cooks in the bottom and cherry tomatoes steam on top, served with olive oil. Not too shabby! The students are still in lockdown in the dormitory, going on four months now. I miss Rolande, a young woman from the DRC. "Roland" is a boy's name, but my young woman friend Rolande, spelt with an " $e$ ", was named after the famous hero of Roncesvalles even so, she tells me. I wish she could come for dinner again, and if only I had some Asiago cheese like I saw at Lille this summer to go with my pasta. I've been thinking like this a lot these days.

Nowhere to escape. Not geographical boundaries, not N95 masks, not social distancing have proved truly effective as a barrier against COVID-19. The one impenetrable defense it cannot breech is the pastness of the past, the safe, upholstered past, safe and secure in its pastness. Pastness stands firm like the gallant knight of Roncesvalles, clad in his impermeable armor who alone halts the virus's spread.

It is early in the day and I am on my way first thing to Xiao Ting's. She finally opened up Moka Town a few days ago and I got to sit there all day drinking lattes and shoring up my reading of Nietzsche's inheritance statements about his father in Ecce Homo with some current research on epigenetic inheritance I got from Doremi. "Doremi" is her English name. She is a former student from when I was teaching at Hangwei, an elite college preparatory school here. She is finishing up her PhD in biology at Harvard now. Like many of the brilliant students who went there, she received full marks on the language section of the SAT - it's in English - and, needless to say, full marks on the math section as well. I think she lost a few points on the writing section and her cumulative score came in at 2360. Some good day that was! I arrive at Xiao Ting's but, alas, she has closed again, shuttered, normal life is not here yet, and I return home. Deb, my former wife, has sent me a few emails. One just said: "They are burying people in Central Park." What? Burying people in Central Park? O my dear god! I practically grew up in the park! I am chilled to the bone, and I crawl back into bed and curl up feeling horribly sick and scared. I am lucky there is someplace else I can go this afternoon, a Milk Tea shop that just opened near to Xiao Ting's. I know the proprietor there, Xiao Gao, and she will sit with me a little while.

Burying people in Central Park, OMG! Deb's one sentence email haunts me and I am shock awake. How come I haven't heard from Angel, Miss Yixin Hu, for two weeks? She is another former student from Hangwei, she was my mentoring student, now at Columbia

1 Thomas Steinbuch, Hangzhou City, Zhejiang Province P.R. China, China.

The Agonist

All rights reserved @ 2021 Transnational Press London 
Business School. I send her another WeChat message. Finally, it's 2 o'clock and time for me to make my way to Xiao Gao's; unsuspecting dear that she is, she is going to help with the outrunning. There's been a lot of construction and I have to pass by a market that regularly advertises on a large circular cutting board out front that a pig's head is on hand. Next day it is steamed and cut up and sold out of a case. There's one now! I arrive at Xiao Gao's first thing she opens with my spanking new Huawei MediaPad that I will use to show her my travel videos to Europe from the past few years, the safe upholstered past. She is chatting with a guy I have never seen before, kind of sturdily built for a Chinese guy I notice. He gives me the once over. I wait for a free moment I can pounce in on their tête à tête to ask her to watch my travel videos with me.

"Hey, Xiao Gao, ever been to Rome? Want to see some videos of my trip there in 2017? How about that Coliseum, eh? And here's the Roman Forum, what a nice day that was, sunny, musicians on the streets, carefree people mingling everywhere. Xiao Gao smiles at me and knows I am sad and she pours me a cup of rice wine in one of those little ornamented cups they have here in China - this one has tiny blue flowers on it. "China woman very like" she says, because I refused at first, and then "I like Bacchus" and she shows me the name "Bacchus" on her phone because her English pronunciation is not good. "Really, that's cool," I say, sipping the rice wine. "I have tons of pictures of Dionysus, from the National Sarcophagi Museum in Istanbul. That is his original name in Greek, can I show them to you?" I do and she becomes instantly involved in the scene, the figure of Dionysus with his crown of ivy-wreath, reclining with his arm crooked over his head, and the satyrs and maenads on the beautifully sculptured Triumph of Dionysus sarcophagus, and I drift right along with her into the past of my trip of to Istanbul in 2013. The rice wine is strong and goes to my head and suddenly the scene takes on a striking familiarity: an arm outstretched offering a cup of wine, a faceoff with guy who looks like he's been on a few odysseys of his own... "Hey, Xiao Gao, you wouldn't know anything about those pigs' heads out there would you? And into my brain stream a few lines from Matthew Arnold's The Strayed Reveler, and I think that maybe like him I have been knocked off course and strayed along to here. "The cup again," solicits the Youth, "ye fade, ye swim, ye waver before me. The cup again." The stranger has propped himself up against a column, numb drunk like the kid in the poem, but Deb's email comes jolting back to me and I check the Huawei to see if I have an answer from Angel. Nope. And now I've had it, and angry thoughts begin to take hold about America's response to COVID-19, I mean Donald Trump's America and his 35\%.

I was flat out sickened when Trump awarded the Presidential Medal of Freedom to Rush Limbaugh. I used to use a cartoon book about Limbaugh in a course on applied logic on the idiocies of "one brain tied behind my back" boy. I'm sorry that Mr. Limbaugh has a terminal disease, but that is neither here nor there: it's the bullying I can't feature as being deserving. I thought we all knew by now that there is something is very wrong with the bully, that he is trying to escape freedom. That was the title of Eric Fromm's famous book, Escape from Freedom. Thus, Medalist Limbaugh accused Dr. Nancy Messonnier of the CDC of letting her bias against President Trump - she is assumed to have such - to be the true reason for her cautions to the public of the possibility of severe disruptions of everyday life. Because her brother supported the wicked Hillary, and incestuous Washingtonians she is incestuous with her brother - (what a piggy little head you have Medalist Limbaugh!) are all out to get Trump. And lots of people believe him, 35\% for sure. So how many lives 
did it cost to ignore her? And then there's Peter Navarro. Navarro thinks he is in a legitimate scientific disagreement with Anthony Fauci over hydroxychloroquine, stating that he has a PhD from Harvard and that scientists disagree all the time and he is a social scientist and hence he gets to "debate" with Fauci. What? "Why, Fauci is the chief buffoon of the professional class" said Tucker Carlson. So we're bullying the smart kids again? Navarro is a Paul Samuelson economist, Samuelson himself was the colorless epigone of Friedrich von Heyak, all wonder to colorlessness that it had not run itself out by then! Mark Linder tore him up pretty well in The Anti-Samuelson. I imagine Doremi calling out Navarro on when exactly it was he supposedly sat foot in a biology laboratory in Harvard. Navarro is a prominent voice in America's chorus of anti-China fanatics, sounding out even more stridently these days as socialism showed what it can do - such as build a giant hospital in six days - and what Americans are foregoing for being "free" - such as a working test for the virus: Road to Serfdom indeed, I'll take it! But then, Navarro is probably one of those guys who thinks he can bully the facts of China's response to COVID-19 out of existence, also probably one of those guys who thinks that Chinese students have "cracked the code" on SAT testing and would just dismiss Doremi's 40 points off full marks out of hand. Right you are my proud boy!

Actually, none of these goings on are new to me as I have been tracking the mind of the bully since childhood. We used to call guys like these "rank out artistes," but usually they mature out by adulthood, that's the only difference today. I remember a rank out artiste I met years back as a substitute teacher in middle school. I wrote a slam poem about him that I used to read at open mic contests. It's called The Seventh Grade:

Bite Mind

He swaggers into the room: "S'up Holmes" he says, making a two-fingered salute, to me/at me G.I. Joe, Sinatra-style Rambo cool.

Brain curls up into protect mode: “Call me 'Holmes' again and I'll chew your fucking face off you prick little piece of shit."

But that's nothing I can say, as perfectly well he knows, no stammering idiolect can unmake the rhyme of his masterful mal mots.

A maestro of orchestrating silence, even my soundless "salve me" goes unheard: sung in reverent sotto voce, he signaled to background for rising din!

Now I'm floundering, helplessly flailing, conjugating to myself, into myself: rage before futility, rage belied by futility, rage after futility.

And what a mind to add new dumbness into the mix, mixing put/down with him/up in his 'S'up'! That's new, something Fat Boy Slim might do, and so deft next to my flubbering fuck you.

I am struck dumb by his new dumbness, I am shut up/shut down completely. Frumpy and frowsy and fumbling, made finally ridiculous, I slump, my chin drops, I'm frozen in mute's caricature. Solid.

Brain Recovering. 
You know, I watched movies of teachers when I was growing up, all turned into eunuchs and impotent and stuff,

Mickey Rooney was in one, but he was just a pup.

I'm swimming in awe seeing myself so stunned. No pup is this kid, he's a top gun.

He's a Top Gun, a Hip-Hop, he’s James Dean at the Last Stop,

all: "get back" and "whadda-ya' got," so menacing next to my argot.

He's Cool Luke so hot in the sun,

A force majeure, a Rat Pack of one,

Why, he knows who played in Peter Gunn!

Then why not just plain-speak to me son,

Speak to me so hot,

'cause you "rat-tat-tat" me like that again and I'm gone.

He is, in short, the Seventh grade of a Seventh grade,

The Perfected Product of the Perfected Civilization,

And you should count yourselves indeed to be very afraid,

as you might be next on his mission of defamation.

The kid zipped fast towards a seat in the back of the classroom because it wasn't crowded yet, he was a little early, and got himself out of earshot before I could reprimand him for disrespect, moving desks around out of his carefully chosen way to drown out any reproof I might mange to sound out, and there I was stuck with the 's'up Holmes' put down. I tried to fight back; my poem became a kind of chanson de geste of articulation as I wrote. But I lost.

Fromm tried to account for how the dominance/submission relationship is an escape from freedom for both parties involved. For those who agree to submission, he is spot on enough, but he stumbles when it comes to the question how the bully is escaping freedom. Fromm was writing at a time when we were being existential about freedom, and that threw his theory into disorder. In epigenetic evolution, we can consider whether the escape from freedom started off as gene regulation caused by the imprint of trauma in the ancient past due to near-extinction events. We have been through six population bottlenecks and releases in the past 70,000 years, the latest possibly as recently as 12,800 years BP. The bully's escape from freedom is a mood disorder, and must be associated to epigenetic regulation induced by trauma in the ancestral past, even if not equally in all populations. Fear of freedom is not inauthenticity as a quasi-moral concept but psychopathology that should be studied as the epigenetic evolution of culture. But why would fear of freedom come out of this? The answer is that we have been traumatized into fear of birth and are afraid of freedom because it means the birth of something. Birth means freedom of 
presence, and we are afraid of freedom because we are afraid to be born. Jean-Luc Nancy seems to have been on track of this in The Birth to Presence, although not the meaning of domination as fear of birth. Domination is a takeover of a second womb to be the escape from birth. The rank-out artiste tires to disprize the subject as an Other of loser of some kind, as nothing so powerful that he cannot make do as told, in a power struggle with autonomy. But it is because he is afraid of it. My autonomy asserts to him that he needs to face being born on his own, that he cannot take me over, and that is what scares him, and so he threatens me to do as told and becomes violent when I won't. The bully is afraid of being born and dominates as a takeover of a second womb. Vide: Capitol Rotunda, January 6, 2021.

Nietzsche was working with the problem of vengefulness against life and the lebensfeindlich culture of Christianity. He spoke of himself as enduring death in life: "whose happiness is death in life" is a good formulation of the riddle to which he is alluding in Ecce Homo (EH "Wise" 1). I have understood him to mean that we are avenging ourselves by hurting life, and that our vengefulness against life has pushed us, himself included, to identification with the agency of death as bringing hurt and crippling to life. He is as Christian as the rest, as he implies by telling us that he attacks only things he has himself has been, as his fifth practice in warfare (variant EH "Wise" 7, KSA 14: 474). Nietzsche did not consider, maybe could not, that there are two poles beyond life. Fear of birth is another adversarial bearing on being alive. The culture that arises from fear of birth is the culture of the bully. I suggest that we call what we are "Species X," as we are not actually a living phylum any longer in these cultures, but are on the poles out beyond life, driven to them by vengefulness and fearfulness encoded in our epigenome by ancestral trauma. So here we are in Trumpland, fear of birth absolutized, demanding to become the order of the world as Nature rages on before us.

In Z: II "On Those Who Are Sublime" we read about the Überbeld of the inexhaustibility of life. He is characterized as resting with his arm crooked over his head, which is a symbol for sexual readiness in the iconography of Dionysus - it was on the Triumph of Dionysus sarcophagus in Istanbul - and I remember something Nietzsche said that was recorded in the orderly report at the Jena Clinic during his institutionalization. He calls for a new nightshirt for the sake of his thoroughgoing Redemption and says that he has been with twenty-four prostitutes during the night (Krell 98). A few months before he confessed in Ecce Homo how he had failed to will the eternal recurrence of his mother and sister (EH "Wise" 3 final draft). But now, in his darkest hour in a psychiatric cell, his commitment authorized by his mother, he succeeds, and that moment of identification with the indestructibility of life is his final Redemption from suffering. Picturing himself celebrating with twenty four prostitutes might have been an allusion to the ancient Roman Flora, an annual revel of prostitutes. The number twenty-four is likely a diss on Siegfried, who won Brunhild proving his manhood 12 times wearing his Cloak of Darkness, so maybe the meaning of the number is that the Nietzschean Überbeld of the inexhaustible renewability life is twice the one that Wagner admired.

To me, the Jena aphorism says that Nietzsche won as champion of the indestructibility of life in his sacred agon against the attack of vengefulness, the first to cross over. But he was in a psychiatric cell after all. How possible? It suggests that Species X's pole of being frightened of birth, full of violence against autonomous self-identification blocking its 
invasiveness, found its way to him. Institutional psychiatry is the enemy of autonomy, as Thomas Szasz made us aware, so I guess no wonder. Species X found its way to maintain itself overall by one pole of its anti-life pathology reaching across to the other pole to find its own way against someone making progress on that pole. So, no Überheld after all. And with no hero to champion the cause of the indestructibility of life, I mean, one who can win, where's the indestructibility? Nietzsche, anyway, was unshakable in his belief in the indestructibly of life, his Dionysian faith come of identifying with the renewability of life that overwhelms any and all suffering. So was the case for Matthew Arnold's Youth, exempt from the law that stipulates the poet's labor and pain in suffering what they sing, as he explains to Ulysses, overtaken in the celebration of life's boundless renewability. The "Over-great fullness of life intoxicates us" Nietzsche says (KSA 13, 14[68]), and we drink to it. I guess I'm just not a rice wine kind of guy. Species $\mathrm{X}$ will always win.

"Tom...Tom," I hear the soft voice of Xiao Gao calling. "I'm closing now. You can come again tomorrow." I will, but I'll get here by the same haphazard way I came today haphazard by reason of the same things as today, shock-awake, picturing burials in Central Park, decomposing bodies in front of out-of-space funeral homes, food queues at the end of which you get a bag of onions, and not by marching to the drum beat of Nietzsche's "a Yes, a No, a straight line, a goal," although I may straight-line my way to a stopover for a snack at the pigs' head case, little cherry tomato garnish on the plate, yum. "Let me check my email first" I say. There's one from Doremi, but oh no, look at the subject line: "Re: Angel, Dear Professor Thomas, I am so sorry to have to tell you.... Ah shit, ah shit...

\section{Works Cited}

Arnold, Matthew. The Strayed Reveler in The Poetical Works of Matthew Arnold, edited by C.B. Tinker and H.F. Lowry. New York/Toronto: Oxford University Press, 1909 185-194. Print.

Fromm, Eric. Escape From Freedom. New York: Farrar \& Rinehart, 1941. Print.

Krell, David Farrell. Nietæsche: A Novel. Albany: State University of New York Press, 1996. Print. In his preface, Krell states: "my translations of the medical reports from the Basel and Jena asylums appear complete" (x).

Linder, Marc, with Julian Sensate Jr. The Anti-Samuelson. New York: Urizen Books, 1972, 2 volumes. Print.

Nancy, Jean-Luc. The Birth to Presence, translated by Brian Holmes. Stanford, California: Stanford University Press, 1997. Print.

Szasz, Thomas S. The Manufacture of Madness. New York: Harper and Row 1970. Print 
Thomas Steinbuch received his $\mathrm{PhD}$ in Philosophy from the University of Massachusetts at Amherst in 1981. He has lived and taught in China for the past ten years and he has retired from Zhejiang University of Science and Technology in Hangzhou. He has focused on the works of Nietzsche for forty years, and he published his Commentary on Nietzsche's Ecce Homo in 1994, with the University Press of America. He has pioneered the epigenetic interpretation of Nietzsche's work to read him as an early explorer of a non-Darwinian model of heritability. He has presented on Nietzsche to SPEP, the APA, the 2012 WCP in Athens and the 2018 WCP in Beijing, to Sadykov Conferences 11 and 111 at Kazan Federal University in Russia, to the School of Marxism, Zhejiang University, Hangzhou China, and to the past six Beyond Humanism Conferences. He is co-founder of the World Posthuman Society with Francesca Ferrando and Yunus Tuncel and co-editor of the journal for the society, Infinity: A Journal for Posthumanists. He maintains a YouTube Channel where can be found a recent and related lecture from December, 2019: "The Marx-Freud Synthesis and The Etiology of Domination in Epigenetic Evolution" and regularly posts his work on academia.edu, http://zust.academia.edu/ThomasSteinbuch. He is presently at work on a three-part series on COVID 19. The first in the series is titled: "Outrunning COVID-19: The Race to Stay Human," and can be found at the posthumans.org/blog website. The second is titled: "Outrunning COVID-19: My Trip to Aeaea," and appears here in this special issue of The Agonist, Nietzsche and Illness, and a third is forthcoming. His most recent article scholarly article in The Agonist is in the Spring Issue 2020, Nietzsche and Sport, and is titled: "Bad Boy Nietzsche!?: The Literature of Alienation in the Late Writings: Ivan Soll on the Chapter titles of Ecce Homo." 